\title{
Synthesis of Schilancitrilactones B and C
}<smiles>COC(=O)C1C(=O)O[C@H]2C=CCC[C@H]12</smiles>

A<smiles>C[C@@H]1[C@H](CC(=O)O)C(=O)O[C@@H]2C=CCC[C@@H]21</smiles>

B

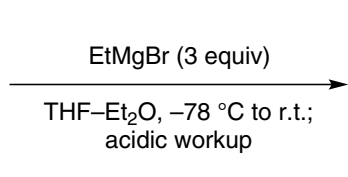

$80 \%$

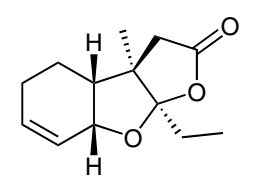

C 2 steps $\checkmark$

1. LDA, E, THF, $-78^{\circ} \mathrm{C}$; then $\mathbf{D}$ $\mathrm{PhMe}, 80^{\circ} \mathrm{C}$<smiles>CCOC(C)(CC)OC(C)(C)/C=C\C1COC(C)(C)C1CCI</smiles>

1. MCPBA, $\mathrm{CH}_{2} \mathrm{Cl}_{2}$

2. $\mathrm{NaOMe}, \mathrm{MeOH}$;<smiles></smiles>

then $\mathrm{NiCl}_{2} \cdot 6 \mathrm{H}_{2} \mathrm{O}, \mathrm{NaBH}_{4}$ $\mathrm{MeOH}-\mathrm{THF},-15^{\circ} \mathrm{C}$
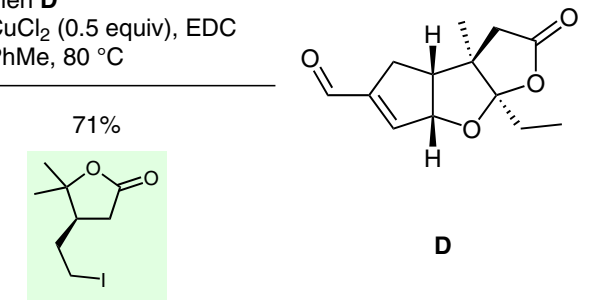

D

E<smiles>CC[C@]12OC(=O)C[C@H]1[C@@H]1CC3(O)C[C@@H]4C(=O)OC(C)(C)C4CCC3[C@@H]1O2</smiles>

2. $\mathrm{CuCl}_{2}$ (0.5 equiv), $\mathrm{EDC}$

Gategory

Synthesis of Natural

Products and

Potential Drugs

\section{Key words}

schilancitrilactone B

schilancitrilactone

terpenoids

conjugate addition

radical coupling

H

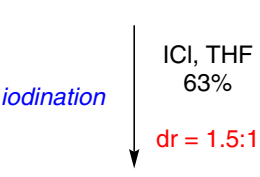

$\mathbf{J}$

J, AIBN, Bu $\mathrm{BnH}_{3}$

$\mathrm{PhMe}, 100^{\circ} \mathrm{C}$

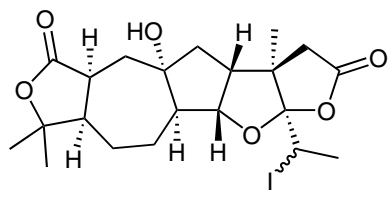

I
Significance: Schilancitrilactones A, B, and C are terpenoid natural products recently isolated from Schisandra lancifolia, a plant used in traditional Chinese medicine. Schilancitrilactone $C$ was shown to exhibit biological activity against HIV-1. The authors disclose total syntheses of schilancitrilactones $\mathrm{B}$ and $\mathrm{C}$.
Comment: Known compound A was converted into enone $\mathbf{F}$ in nine steps. Intramolecular conjugate addition in aqueous pyridine followed by epoxidation, E1cb-type ring opening, and conjugate reduction set the stage for iodination of the acetal in $\mathbf{H}$. Radical coupling with stannane $\mathbf{J}$ afforded the two natural products.

SYNFACTS Contributors: Erick M. Carreira, Matthias Westphal

Dol: 10.1055/s-0034-1380782; Reg-No.: C02215SF 